\title{
The Liquidity Discount in the Italian Market
}

\author{
Emanuel Bagna ${ }^{1}$ \\ ${ }^{1}$ Pavia University, Italy \\ Correspondence: Emanuel Bagna, Pavia University, Via S. Felice Al Monastero 5, 27100 Pavia PV, Italy.
}

Received: October 5, 2020

Accepted: October 27, $2020 \quad$ Online Published: October 27, 2020

doi:10.5539/ibr.v13n11p137

URL: https://doi.org/10.5539/ibr.v13n11p137

\begin{abstract}
The illiquidity discount represents the reduction in the value of an asset because it cannot be easily sold. It is usually applied by appraisals in valuing a minority interest in a closely-held business. This article presents a literature review of the illiquidity discount and an analysis of the level of discount in Italy during the period 2003 - 2012. The analysis conducted made it possible to verify: a) the existence for the Italian market of a discount for lack of liquidity for shares with less turnover; b) the variability over time of that discount, thus agreeing with the literature that has found the premiums for liquidity risk vary over time. The discounts that were found are, nonetheless, smaller than those indicated in the literature. The descending trend over time for the discount would seem to be particularly consistent with the studies on restricted stocks.
\end{abstract}

Keywords: valuation, liquidity discount, market multiples

JEL classification: G32, G12, G30

\section{Introduction}

When deciding whether to acquire a minority stake in an unlisted company, an expert normally has to apply a discount because of the lack of liquidity. The discount is justified by the increased costs the investor would incur when selling the stake, because the company is not listed on a stock market. Compared to a stake in a listed company, an investor would incur:

- increased transaction costs;

- $\quad$ an opportunity cost determined by the time need to find a counterparty;

- the (specific and systemic) risk that, during the period needed to find a counterparty, the market conditions or the state of the company itself could take a turn for the worse.

The same Appendix A of IAS 36 on estimating the recoverable value of goodwill and a company states, in paragraph 1, "Using present value techniques to measure value in use" as in the calculation of the present value of an asset must also take into account "...other, sometimes unidentifiable, factors (such as illiquidity) that market participants would reflect in pricing the future cash flows the entity expects to derive from the asset."

In principle, the discount in question should make an investor indifferent to two alternative assets - one liquid, one illiquid - with the same payoff. In other words, the illiquid investment should offer forecast returns above those expected from the liquid asset.

When it comes to actually appraising such a discount, there is little debate about the need to apply a discount to the fundamental value of an illiquid security or pool of securities (such as a stake in an unlisted company) because of the lack of liquidity, but there is plenty of debate about the method to be used to estimate the discount and the size of the discount.

Focusing on the method for estimating the discount, there are two options.

a) The first option is actually used in practice and involves applying a discount for the lack of liquidity after having appraised the stake as if it were liquid;

b) The second option comes from the literature and involves applying a premium to the opportunity cost of capital for the liquidity risk.

This article starts by defining the liquidity attribute for a security (or a stake) before conducting an assessment to determine if and to what degree liquidity is "priced" by the market. This is followed by a presentation of the 
theoretical framework underlying adjustments to discount rates for a lack of liquidity. The third section looks at the various methodologies found in the literature to determine the liquidity discount, focusing specifically on the limits of those methodologies. The final section presents a model for determining the discount based on the Italian market between 2003 and 2012.

\section{Liquidity and Markets}

The liquidity of an asset refers to the speed and ease with which it can be transformed into cash when desired, at a fundamental value and without having to give up part of the value because of the urgency of the sale.

Is illiquidity is an isolated issues that only troubles unlisted securities, or is it also found in financial markets?

Answering this question requires setting out two measurements: one that shows the speed with which a financial asset can be sold and the other that shows the probability of selling it at a discount. In the literature, these two measurements are known respectively as turnover and the bid-ask spread. Turnover is the number of shares transacted in a specific period compared to a company's total number of shares. By contrast, the bid-ask spread shows the differential between the purchase price and the sales price for a listed share on the same date. This indicator is generally expressed in relation to the price of the security, so as to obtain a discount measurement.

In efficient markets, the high numbers of trades for a security ensure a stake can be rapidly sold, just as a low bid-ask spread ensures the security can be sold at a price close to the fundamental value. In a diametrically opposed sense, low volumes and a high bid-ask spread make it possible to transfer a stake at a price that is quite far removed from the fundamental value, at a significant discount. Take, for example, the purchase of $€ 200,000$ worth of securities in a liquid company and the same amount in an illiquid company. For 2020, the annual average daily bid-ask spreads (relative to the price) are $0.05 \%$ and $5.93 \%$ respectively. Moreover, the securities have an annual average daily turnover of $0.31 \%$ and $0.01 \%$ respectively. Assuming theoretical capital gains for both securities of $12 \%$, an investor decides to sell both assets. With capitalisation at 31/12/2019 for both securities of $€ 2,801$ million and $€ 70$ million respectively, there would be no problem selling the liquid security as the average daily volume $(0.31 \%)$ effectively guarantees a rapid sale. Imagining brokerage fees of 20 basis points and a bid-ask spread equal to the annual daily average, the gains would be $11.75 \%$ (equal to $12 \%-0.20 \%-0.05 \%=11.75 \%)$. The scenario is not the same for the illiquid asset, where the realisable gain would be far lower $(12 \%-0.20 \%-5.93 \%=5.87 \%)$. Additionally, such a gain might be purely theoretical because, as the capital share owned by the investor is equal to $0.32 \%(200,000 \times 1.12 \% / 70,000,000)$, the market would only be able to absorb such an amount in 32 days ( $32=$ capital share held $/$ average daily turnover $=0.32 / 0.01$ ).

This example shows how liquidity is also an issue that is relevant to regulated markets.

Accepting the hypothesis that securities lacking liquidity offer higher returns, one would expect to find relatively lower prices for these securities if the fundamentals are basically the same. Likewise, highly liquid securities should have relatively high prices. This means the share price discounts because of the lack of liquidity should be matched by risk premiums in the discount rates of the expected results (cost of capital). This is the outlook adopted by the IAS and referenced in the introduction.

Imagine, for example, two companies (Alfa and Beta) with identical payoffs, but with different liquidity levels. Let's assume the value of both securities can be calculated using a dividend discount model (DDM). The dividends are equal to 10, the cost of capital - calculated according to the Capital Asset Pricing Model - is 10\%, the dividend growth rate in perpetuity is 0 and the book value is 100 . The value of both securities is:

$\mathrm{W}_{\text {Alfa }}=\mathrm{W}_{\text {Beta }}=$ Dividend $/$ Cost of Capital $=10 / 0.10=100$,

and the Price to Book Value multiple $(\mathrm{P} / \mathrm{BV})$ is:

$\mathrm{P} / \mathrm{BV}_{\mathrm{Alfa}}=\mathrm{P} / \mathrm{BV}_{\text {Beta }}=\mathrm{W}_{\text {Alfa }} / \mathrm{BV}_{\text {Alfa }}=\mathrm{W}_{\text {Beta }} / \mathrm{BV}_{\text {Beta }}=100 / 100=1 \mathrm{x}$.

The risk premium for a lack of liquidity for Alfa is $1 \%$ (to be added to the cost of capital) and the premium for Beta is 0 . The value and multiple of the equity for the Beta security would remain unchanged, but for the Alfa security, the value and multiple would be less:

$\mathrm{W}_{\text {Alfa }}=10 /(0.10+0.01)=90.91$

$\mathrm{P} / \mathrm{BV}_{\text {Alfa }}=90.91 / 100=0.91 \mathrm{x}$

\section{Adjusting Cost of Capital for Lack of Liquidity}

The efficiency of financial markets means that two activities with the same payoff (same forecast cash flow and 
identical risk) must have the same price. ${ }^{1}$ Any discrepancy would open up the possibility of making a profit without taking on the risk (arbitrage), buying the undervalued asset and selling the overvalued one. The greater any such price divergence (and hence profit), the greater the number of investors that would be interested. The excess of demand (offer) for the undervalued (overvalued) asset would lead to a realignment of prices, guaranteeing market equilibrium and efficiency. Now, let us assume we have two securities - one liquid and the other illiquid - available on the same market, with an identical payoff but consistently different prices. Is our only conclusion that the market is inefficient?

If one accepts the hypothesis that securities lacking liquidity have an opportunity cost of capital above what is justified by the covariance between their returns and those of the market, the answer would probably be "no".

Amihud and Mendelsson (1986) were the first to demonstrate that securities with a high bid-ask spread have higher yields. Focusing on the period 1961-1980, their analysis showed how the average monthly returns on securities listed on US markets with a higher bid-spread ask were 67 basis point above that of securities with a lower bid-ask spread. ${ }^{2}$

However, it was a subsequent study by Roll, Chordia and Subrahmanyam (2000) that questioned the Capital Asset Pricing Model, showing liquidity risk is systemic and so hard to diversify. Achraya and Pedersen (2003) then used this study as a basis to go further and show that illiquid securities have a risk premium $1.1 \%$ higher than that of liquid securities, and that such a premium was largely explained (80\%) by the covariance between the liquidity of a security and the liquidity of the market. Hence, the differential in the illiquidity risk premium between illiquid and liquid securities is greater during periods in which the market itself is illiquid. Stambaugh and Pastor (2003) reached the same conclusions.

The difficulty in estimating the coefficients for the sensitivity of the liquidity of a security to changes in market liquidity (liquidity beta) led to various authors proposing adjustments to rates only on the basis of turnover or the bid-ask spread of a security. Amihud and Mendelsson (1989) proposed adjusting rates by 24/26 basis points annually for each percentage point increase in the bid-ask spread. Assuming the same cost of capital for Boero Bartolomeo and Italcementi shares (calculated using the Capital Asset Pricing Model) at 7\%, the adjustment of that cost for Italcementi would be almost zero $(0.12 \%=0.05 \%$ x $0.24 \%)$, while for Boero Bartolomeo it would be significant $(1.42 \%=5.93 \%$ x 0.24\%). By contrast, Datar, Nair and Radcliff (1998) proposed using turnover levels for such an adjustment. Their idea was for each percentage point increase in turnover, one should see a $0.54 \%$ drop in the annual expected returns. Taken together, these studies show discount rates should be adjusted for a security's liquidity risk. However, the lack of a universally accepted model and, more importantly, a model that can be used in practice (neither bid-ask spread nor turnover can be used for unlisted securities) leads to the notion it is best to initially estimate the value of an illiquid minority stake as if it were liquid and then apply a discount for lack of liquidity. Precisely such an approach is recommended by the American Institute of Certified Public Accountants (AICPA) in the exposure draft on standards for valuation. ${ }^{3}$ In point 42 of the document, one finds: "Examples of valuation adjustments for valuation of a business... include a discount for lack of marketability and a discount for lack of control."

\section{A Discount for a Lack of Liquidity: Review of the Proposed Methods (Literature Review)}

The methodologies proposed in the literature (both academic and non) to estimate the discount for a lack of liquidity hinge on finding situations in which a security is simultaneously traded on an organised market (liquid) and independently (illiquid). This is precisely the case for "restricted stocks" - shares of listed companies that are placed privately without soliciting funds from the public at a significant discount compared to the same shares traded on the market. An alternative is securities sold to a third-party company before being placed on the stock market. These studies (called "IPO studies" below) are based on the details of how the shares for companies about to list are sold at a discount on the placement price. The third area of study focuses on comparing the multiples for the purchase of a controlling stake of a listed companies with the same multiples for comparable unlisted companies (called "Public/private company transactions" below).

\section{A) Restricted stocks}

Most of the information about the discount for lack of liquidity comes from studies of restricted stocks. These

\footnotetext{
${ }^{1}$ In the literature, this relationship is known as the law of one price.

${ }^{2}$ Expressed in annual terms, this corresponds to an $8 \%$ yield premium for securities with less liquidity, meaning it is close to the historical risk premium for the S\&P 500!

3 "Proposed Statement on Standards for Valuation Services", AICPA, March 2005.
} 
are shares of listed companies that are placed privately with a restricted section of the public, without any prospectuses being published. As a consequence, the American supervisory authority (the Securities Exchange Commission or SEC) bans the resale (on a regulated market) of securities so acquired for a year (SEC Rule 144). Such a security is illiquid and so it is placed at a significant discount compared to the prices for the same shares listed on the market.

Table 1 shows the liquidity discounts since the SEC study in 1969. The table highlight that the discount is less for those samples of companies analysed in the more recent past. For example, the study conducted by Columbia Financial Advisor underscores how, between 1996 and 1998, the discount dropped from 21\% to 13\%. This could be tied to a rule change for trading restricted stocks (SEC Rule 144), as before 1997 there were more restrictions on the sale of such securities (a restricted stock could only be sold two years after its purchase). This downward trend might also be explained by the general increase in available liquidity in recent years, with the consequent (upward) pressure on the prices of illiquid assets.

Table 1. Discount for lack of liquidity derived from the restricted stock studies

\begin{tabular}{|l|c|c|}
\hline \multicolumn{1}{|c|}{ Study } & $\begin{array}{c}\text { Period for } \\
\text { study }\end{array}$ & Average Liquidity Discount \\
\hline SEC & $1966-1969$ & $26 \%$ \\
\hline Gelman & $1968-1970$ & $33 \%$ \\
\hline Trout & $1968-1972$ & $33 \%$ \\
\hline Maher & $1969-1973$ & $35 \%$ \\
\hline Moroney & $1969-1973$ & $36 \%$ \\
\hline Stryket, Pittock & $1978-1982$ & $45 \%$ \\
\hline Hall, Polacek & $1979-1992$ & $23 \%$ \\
\hline Hertzel, Smith & $1980-1987$ & $14 \%$ \\
\hline Management Planning, Inc. & $1980-1995$ & $28 \%$ \\
\hline FMV Opinions, Inc. & $1980-1997$ & $22 \%$ \\
\hline Willamette & $1981-1984$ & $31 \%$ \\
\hline Silber & $1981-1988$ & $34 \%$ \\
\hline Bajai, Denis, Ferris, Sarin & $1990-1995$ & $7 \%$ \\
\hline Johnson & $1991-1995$ & $20 \%$ \\
\hline Finnerty & $1991-1997$ & $20 \%$ \\
\hline Columbia Financial Advisor (1) & $1996-1997$ & $21 \%$ \\
\hline Columbia Financial Advisor (2) & $1997-1998$ & $13 \%$ \\
\hline
\end{tabular}

Source: our calculations using Pratt (2001) and Hitchner (2003), Bajai et al. (2001) and Finnerty (2002)

One key aspect that is common to all these studies is the significant dispersion of the discount within the sample. Silber (1991) was the first to seek the reasons for this. He showed that larger, more financially solid companies had a smallish discount at $14 \%$, but small, less financially solid companies had an average discount of $60 \%$. Subsequent studies have confirmed this ${ }^{4}$ using different variables for the health/risk of a company ${ }^{5}$ and its size.

The primary limitation of such studies is that the discount is measured over lengthy periods, up to a decade at times. This paper has already highlighted the time relevance of the liquidity of a security. It is highly unlikely that, say, the stock for a tech company had the same illiquidity characteristics (and consequently the same discount) in early 2000 at the height of the bubble and in September 2001 (when the Twin Towers were attacked).

Such studies also suffer from the potential limitation that, in the selected private placements, the transfer of stock is to company insiders. Thus, the discount could be due to alternative forms of bonuses/compensation.

Let us now imagine we have purchased shares in a listed company through a private placement. This entails

${ }^{4}$ See, for example, Bajaj, Denis, Ferris and Sarin (2001).

${ }^{5}$ Such as the volatility of profits, of market returns and so on. 
giving up the ability, guaranteed by an efficient regulated market, to sell them at their fundamental value, without having to grant any discounts. However, if the ability to sell an asset at a set price (fundamental value) is the same as a defined put option, we can see the purchase of the security in a private placement as implicitly giving up a put option for the same security. Such reasoning drove Chaffee (1993) to see the liquidity discount implicit in the purchase of restricted stocks as an option. He argued the difference between the purchase price for a security in a private placement and the related market price was the equivalent of the price of a put option (at the money) for the security. Since the key aspects that determine the price of an option are its maturity and the volatility of the underlying, it follows that the liquidity discount on a stake would increase as:

- the uncertainty and risk of the investment increase (as reflected in increased price volatility);

- the period for which the security is illiquid increases, in this case equal to one year.

Chaffee does show an effective correlation between the discount for lack of liquidity applied to restricted stocks and the price for a put option at the money with maturity at one year for the same security, ${ }^{6}$ but using such a methodology to determine the discount for completely illiquid securities (and thus not restricted stocks) would be complicated in practice as, in reality, the data to calculate the volatility of returns is not available.

\section{B) IPO studies}

One way of measuring the liquidity discount is to compare the sale prices for a share prior to a company being listed and the prices after listing. Such an approach is adopted by Emory, Willamette Management Associates (WMA) and Hitchner. ${ }^{7}$ Emory found the average discount for lack of liquidity was $45 \%$, based on an examination of the transactions in the five months prior to a company listing. The available details also show the discount for lack of liquidity determined using this approach is independent of the period in which the transaction was performed. The average discount is between $40 \%$ and $45 \%$ for the period 1980-2000, with the only exclusions being 1980-1981 (average discount of 66\%) and 1997-2000 (average discount of 52\% ${ }^{8}$ ). The study found that, during other periods, liquidity was only minimally linked to the time period.

Contrastingly, the studies by WMA and Hitchner found the discount to be variable in relation to the period in which it was calculated (discounts ranged from a minimum of $31.8 \%$ for 1991 , to $73.1 \%$ for 1984).

One of the criticisms tabled against the Emory, WMA and Hitchner studies is the different types of investors involved in the purchase. In many cases, the purchase of a security prior to its placement is done by stakeholders within the company (management or venture capitalists), while the post-listing purchases are generally by non-strategic investors. Thus, the discount for purchasing a package of shares could be due to it being some form of bonus/compensation for the company's management or a form of remuneration for the services provided by a venture capitalist.

Secondly, the discount calculated using such an approach could be distorted by divergent growth prospects for the company between when the private transaction occurred and the moment when the company's shares were listed. ${ }^{9}$ A portion of the difference between the prices for pre and post placement discounts could be due to increased uncertainty about a company's future.

Let us use an example to explore the logic underlying this criticism. Imagine a venture capitalist purchases a minority stake in a company that is planning to list. The company can be analysed using a dividend discount model (DDM). The dividend per share is 10 , the cost of equity is $10 \%$ and the dividend growth rate is $1 \%$. The dividend growth rate is uncertain because the company is in the middle of negotiations that could lead to a joint venture with a competitor that would increase the dividend growth rate in perpetuity to $3 \%$. Should the negotiations prove successful (we assume a $10 \%$ probability of success) the company will list. What would the company be worth in this case? Should the joint venture come to fruition, the value would be:

$\mathrm{W}_{\text {cum joint venture }}=\mathrm{D} /(\mathrm{coe}-\mathrm{g})=10 /(0.10-0.03)=10 / 0.07=142.86$

\footnotetext{
${ }^{6}$ The value of the put option at the money is calculated using the Black Scholes formula.

7 The database for the Emory analysis is available at: http://www.emorybizval.com/.

${ }^{8}$ For this period, Emory divided the sample into tech stock (dot.com) and non-tech stock. The discount for tech stock was $54 \%$, while for the others it was $44 \%$.

${ }^{9}$ The WMA studies looked at all the transactions in the three years prior to the IPO, adjusting the discount for a lack of liquidity for any change in the P/E multiple for the industry in which the company operates in the period prior to placement.
} 
But if the joint venture never actually happens:

$\mathrm{W}_{\text {ex joint venture }}=\mathrm{D} /(\mathrm{coe}-\mathrm{g})=10 /(0.10-0.01)=10 / 0.09=111.11$

The fair value for the security would be the sum of the probability of the two events happening, multiplied by the values calculated previously:

$\mathrm{W}=\mathrm{W}_{\text {cum joint venture }} \mathrm{x} 0.10+\mathrm{W}_{\text {ex joint venture }} \mathrm{x} 0.90=142.86 \times 0.10+111.11 \times 0.90=114.29$

Imagine an investor purchases a minority stake in the company at fair value, receiving a discount for lack of liquidity of $30 \%$. The transaction would take place at $€ 80$ per share $(114.29 \times 0.70=80)$. Now, let's also imagine the negotiations prove successful. The fundamental value of the share would be $€ 142.86$ per share. Drawing on the methodology adopted by Emory, the discount would be $44 \%$ (1-80/142.86), but the discount actually negotiated is $30 \%$.

\section{C) Public/private company transactions}

The third approach to estimate the discount for a lack of liquidity is based on comparing observable multiples for listed companies and observable multiples for unlisted companies. Koeplin, Sarin and Shapiro (2000) selected 84 transactions to purchase majority stakes in the United States and 108 transactions outside of the US. For each purchase of an unlisted company, a comparable transaction (industry, year and nation) was found for a listed company. The liquidity discount was then calculated using this formula:

Liquidity Discount $=1-[$ (Implied Market Multiple in the acquisition of unlisted companies $) /$ (Implied Market Multiple in the acquisition of listed companies)]

Table 2 provides the information from the verification by the authors. Referring only to the statistically significant discounts, it becomes evident the median discount for a lack of liquidity in the United States varies from $18.14 \%$ to $30.62 \%$, depending on whether one uses the Enterprise Value/Ebitda multiple or the Enterprise Value/Ebit multiple. Internationally, the discount in question has significantly different values depending on whether one uses the Enterprise Value/Ebit multiple (discount of 5.96\%) or the Enterprise Value/Ebitda multiple $(23.49 \%)$.

Table 2. Discounts for lack of liquidity identified by the Koeplin, Sarin and Shapiro analysis

\begin{tabular}{|l|c|c|c|c|}
\hline \multicolumn{2}{|c|}{ US Transactions } & \multicolumn{2}{c|}{ International transactions } \\
\hline $\begin{array}{l}\text { Multiple implicit in Acquisitions of } \\
\text { Unlisted Companies }\end{array}$ & Median & Average & Median & Average \\
\hline Enterprise Value/Ebit & 8.58 & 11.76 & 11.37 & 16.26 \\
\hline Enterprise Value/Ebitda & 6.98 & 8.08 & 7.1 & 11.96 \\
\hline Enterprise Value/Book Value & 1.85 & 2.35 & 1.35 & 2.41 \\
\hline Enterprise Value/Sales & 1.13 & 1.35 & 1.35 & 2.63 \\
\hline & & & & \\
\hline $\begin{array}{l}\text { Multiple implicit in Acquisitions of } \\
\text { Listed Companies }\end{array}$ & & & & \\
\hline Enterprise Value/Ebit & 12.47 & 16.39 & 12.09 & 28.97 \\
\hline Enterprise Value/Ebitda & 8.53 & 10.15 & 9.28 & 25.91 \\
\hline Enterprise Value/Book Value & 1.73 & 2.86 & 1.68 & 3.7 \\
\hline Enterprise Value/Sales & 1.14 & 1.32 & 1.63 & 4.59 \\
\hline & & & & \\
\hline Implicit liquidity discount & & & & $43.87 * * *$ \\
\hline Enterprise Value/Ebit & $30.62^{* * *}$ & $28.26^{* * *}$ & $5.96^{* *}$ & $33.85^{* *}$ \\
\hline Enterprise Value/Ebitda & $18.14 * * *$ & $20.39^{* * *}$ & $23.49^{*}$ & \\
\hline Enterprise Value/Book Value & -7.00 & $17.81^{* * *}$ & 19.64 & 34.86 \\
\hline Enterprise Value/Sales & 0.79 & -2.28 & 17.18 & 42.70 \\
\hline
\end{tabular}

*One asterisk indicates a data significance level of $10 \%$, two asterisks, a significance of $5 \%$, three asterisks a high statistical significance (1\%).

Source: adapted from Koeplin, Sarin and Shapiro (2000)

The major criticism of Koeplin, Sarin and Shapiro is whether a private and a public company can actually be compared. Moreover, the study fails to analyse variables that might also influence the extent of the discount (such as the company's profitability). 
Accepting that a liquidity discount must make an investor indifferent as to whether to invest in liquid securities or illiquid securities with an identical payoff, it become possible to assign a score on three elements for the models summarised above:
A) Degree to which the payoff is identical between the liquid and illiquid asset;
B) Effective comparability of the sale price of the liquid asset and the price of the illiquid asset;
C) The temporal dispersion in the determination of the liquidity discount.

Table 3 shows the best model for estimating the liquidity discount, in terms of profiles A and B, is the restricted stock approach, while the best option for profile $\mathrm{C}$ is the comparable transactions approach. Studies of restricted stocks also have the advantage of highlighting how the liquidity discount is dependent on specific factors at the company in question.

Table 3. Compares the methodologies proposed in the literature to estimate the liquidity discount

\begin{tabular}{|l|c|l|l|l|}
\cline { 2 - 5 } \multicolumn{1}{l|}{} & $\begin{array}{l}\text { A) Degree to which the } \\
\text { payoff is identical } \\
\text { between the liquid and } \\
\text { illiquid asset }\end{array}$ & $\begin{array}{l}\text { B) Effective } \\
\text { comparability of the sales } \\
\text { prices for the liquid asset } \\
\text { and the illiquid asset }\end{array}$ & $\begin{array}{l}\text { C) } \\
\text { dispersion } \\
\text { determining } \\
\text { prices }\end{array}$ & of \\
\hline Restricted Stock Studies & +++ & +++ & + & +++++++ \\
\hline IPO Studies & ++ & + & ++ & +++++ \\
\hline Comparable transactions & + & ++ & +++ & ++++++ \\
\hline
\end{tabular}

\section{Liquidity Discount Estimates in the Italian Market}

The focus of this section is to find a measurement for the liquidity discount to apply to minority stakes in unlisted companies operating in Italy. Rather than adopt one of the discount methods covered above, it was decided to use a market approach - drawing on some aspects on the method used by Koeplin, Sarin and Shapiro by asking what multiple a listed company would have if it were not listed. One of the fundamentals of this assessment draws on the evidence that liquidity is priced by the market, such that more liquid securities have higher multiples.

From 2003 to 2019, the Italian stock exchange was characterised by the presence of numerous listed companies with very low trading volumes. Grouping the listed companies into deciles based on stock market trading (turnover), the level of trading for the companies in the first decile is $2 \%$, which is definitely comparable with unlisted companies (private companies). Since there is a direct relationship between the liquidity level (turnover) of shares and the stock exchange multiples (higher multiples mean more trading and visa-versa), as has been well-established in the literature, it is possible to deduce the liquidity discount based on the differential in the multiples for the most liquid securities (tenth decile) and the most illiquid securities (first decile), and then analyse the dynamics of this differential over time.

The sample of companies used here is all the Italian listed companies in the 17-year period from 2003 to 2019. The Price to Book Value multiple at 31 December of each year was calculated for each company, on the basis of its capitalisation and common equity. To measure the liquidity of different shares, the turnover indicator was used, corresponding to the number of shares traded in a specific period (in the case in hand in the last three months) relative to the total number of shares of a company. To have a way of measuring the discount for lack of liquidity two alternatives were used:

a) the Price to Book Value (P/BV) for companies with the greatest turnover was calculated and compared to the same measurement for those with the lowest turnover. In this case, the multiples were only calculated for companies in the first and tenth deciles for turnover. The discount was calculated using this formula:

Liquidity Discount $t_{\mathrm{t}}=1-\left[\left(\right.\right.$ Median Price to Book Value $_{\mathrm{t}}$ for companies with low turnover) / (Median Price to Book Value ${ }_{t}$ for companies with high turnover)] 
b) the Price to Book Value for all Italian companies was regressed at the end of each year on the turnover indicator. In this case, all the companies were examined. When turnover is a statistically significant variable in the regression, the liquidity discount can be determined by the percentage difference between:

- the Price to Book Value multiple for an illiquid company obtained by using a turnover value of 0 in the regression;

- the Price to Book Value multiple for a liquid company, assuming turnover equal to the median of the companies in the tenth decile of the turnover frequency distribution (most liquid companies).

The two analyses are shown in detail below, along with the related results.

Comparison between the Price to Book Value multiple for companies with high and low turnover

The analysis involved the 305 listed Italian companies in each year in the ten-year period from 2003 to 2019. Turnover at three months and the P/BV multiple were calculated for each company. Then, all the companies were ordered according to turnover and then grouped into deciles. As such, the first deciles have the least liquid companies, while the final deciles have the greatest liquidity. The descriptive statistics for the deciles are presented in figure 1 and make it possible to compare:

- the median P/BV multiple for companies with high turnover, that is, those in the tenth decile for the frequency distribution of the turnover indicator for Italian listed companies;

- $\quad$ and the same multiple for companies with low turnover, that is, the companies in the first decile for the frequency distribution of the turnover indicator.

The result from the analysis in figure 1 and table 4 reveal the following:

1. The companies with low turnover can basically be seen as the same as private companies. In this sense, the average turnover for companies in the first decile for 2003-2019 was basically zero (on average, $2 \%)$.

2. The correlation between the P/BV multiple and turnover varies significantly from year to year (called the time varying correlation). As such, for years such as 2006, 2007 and 2010, where the correlation is high, there are other years - 2008, 2009, 2011 and 2012 - in which the two measurements have no substantial correlation. This means that, as has been shown in the literature, liquidity is a determining factor in the price of a company only in some years, but in others it clearly is not.

3. Nonetheless, the correlation level does follow a long-term trend and tended to decrease during the ten-year period at an average annual rate of $8.3 \%$. in 2012 , there is no longer any relationship between the P/BV multiple and turnover.

4. Due to the increasingly small correlation over time, there is a significant, parallel reduction in the discount for lack of liquidity (calculated as shown above) between 2003 and 2019. The discount decreased in the ten-year period in question at an average annual rate of $4.2 \%$.

Table 4. The liquidity discount and the correlation between liquidity of shares and the P/BV multiple in the seventy-year period from 2003-2019

\begin{tabular}{|c|c|c|c|c|c|c|c|c|c|c|c|c|}
\hline & \multicolumn{2}{|c|}{2003} & \multicolumn{2}{|c|}{2004} & \multicolumn{2}{|c|}{2005} & \multicolumn{2}{|c|}{2006} & \multicolumn{2}{|c|}{2007} & \multicolumn{2}{|c|}{2008} \\
\hline & Turnover & $\mathbf{P} / \mathbf{B V}$ & Turnover & $\mathbf{P} / \mathbf{B V}$ & Turnover & P/BV & Turnover & $\mathbf{P} / \mathbf{B V}$ & Turnover & $\mathbf{P} / \mathbf{B V}$ & Turnover & $\mathbf{P} / \mathbf{B V}$ \\
\hline Decile 1 & $2,0 \%$ & $1,29 \mathrm{x}$ & $2,8 \%$ & $1,76 \mathrm{x}$ & $2,9 \%$ & $1,38 \mathrm{x}$ & $3,8 \%$ & $1,29 \mathrm{x}$ & $2,4 \%$ & $1,32 x$ & $1,1 \%$ & $1,07 x$ \\
\hline Decile 2 & $3,1 \%$ & $1,41 \mathrm{x}$ & $3,7 \%$ & $1,14 \mathrm{x}$ & $4,5 \%$ & $1,49 \mathrm{x}$ & $5,5 \%$ & $1,89 \mathrm{x}$ & $4,2 \%$ & $1,52 \mathrm{x}$ & $1,8 \%$ & $0,85 x$ \\
\hline Decile 3 & $4,7 \%$ & $1,52 \mathrm{x}$ & $5,9 \%$ & $1,89 \mathrm{x}$ & $7,1 \%$ & $1,67 \mathrm{x}$ & $8,5 \%$ & $1,93 x$ & $5,5 \%$ & $1,73 \mathrm{x}$ & $2,8 \%$ & $1,61 \mathrm{x}$ \\
\hline Decile 4 & $7,2 \%$ & $1,41 \mathrm{x}$ & $8,2 \%$ & $1,48 \mathrm{x}$ & $9,4 \%$ & $1,82 \mathrm{x}$ & $10,3 \%$ & $1,96 \mathrm{x}$ & $7,4 \%$ & $1,72 \mathrm{x}$ & $3,6 \%$ & $0,79 \mathrm{x}$ \\
\hline Decile 5 & $9,3 \%$ & $1,96 \mathrm{x}$ & $10,6 \%$ & $1,65 x$ & $11,5 \%$ & $1,82 \mathrm{x}$ & $14,2 \%$ & $1,91 \mathrm{x}$ & $11,1 \%$ & $2,21 x$ & $5,6 \%$ & $0,85 x$ \\
\hline Decile 6 & $11,8 \%$ & $1,43 x$ & $13,2 \%$ & $1,49 \mathrm{x}$ & $17,2 \%$ & $1,86 \mathrm{x}$ & $18,6 \%$ & $2,53 x$ & $14,2 \%$ & $1,73 x$ & $8,2 \%$ & $0,73 x$ \\
\hline Decile 7 & $16,3 \%$ & $1,01 x$ & $16,4 \%$ & $1,90 x$ & $22,7 \%$ & $1,43 x$ & $21,4 \%$ & $2,27 x$ & $19,3 \%$ & $2,23 x$ & $10,3 \%$ & $1,23 x$ \\
\hline Decile 8 & $23,9 \%$ & $1,49 \mathrm{x}$ & $23,3 \%$ & $1,91 \mathrm{x}$ & $27,3 \%$ & $2,14 \mathrm{x}$ & $30,9 \%$ & $2,38 \mathrm{x}$ & $28,3 \%$ & $2,05 x$ & $15,2 \%$ & $0,95 x$ \\
\hline Decile 9 & $32,3 \%$ & $2,08 x$ & $32,5 \%$ & $2,40 \mathrm{x}$ & $42,0 \%$ & $2,29 \mathrm{x}$ & $41,0 \%$ & $2,61 x$ & $41,9 \%$ & $2,27 x$ & $23,4 \%$ & $0,89 \mathrm{x}$ \\
\hline Decile 10 & $56,8 \%$ & $2,38 x$ & $65,0 \%$ & $1,93 \mathrm{x}$ & $72,3 \%$ & $2,16 x$ & $63,5 \%$ & $2,19 \mathrm{x}$ & $77,0 \%$ & $2,08 x$ & $44,4 \%$ & $1,03 x$ \\
\hline Median Whole Sample & $10,3 \%$ & $1,47 x$ & $11,5 \%$ & $1,63 x$ & $14,6 \%$ & $1,79 \mathrm{x}$ & $16,4 \%$ & $2,00 x$ & $12,8 \%$ & $1,92 x$ & $6,6 \%$ & $0,94 x$ \\
\hline Implied Discount - Dec & & $45,8 \%$ & & $8,6 \%$ & & $35,9 \%$ & & $40,8 \%$ & & $36,2 \%$ & & $-4,5 \%$ \\
\hline Implied Discount - Med & & $34,2 \%$ & & $-7,1 \%$ & & $23,8 \%$ & & $32,1 \%$ & & $40,0 \%$ & & $-26,1 \%$ \\
\hline Correlation & & $73,1 \%$ & & $51,6 \%$ & & $71,2 \%$ & & $58,1 \%$ & & $56,6 \%$ & & $-6,3 \%$ \\
\hline
\end{tabular}




\begin{tabular}{|c|c|c|c|c|c|c|c|c|c|c|c|c|}
\hline & \multicolumn{2}{|l|}{2009} & \multicolumn{2}{|l|}{2010} & \multicolumn{2}{|l|}{2011} & \multicolumn{2}{|c|}{2012} & \multicolumn{2}{|c|}{2013} & \multicolumn{2}{|c|}{2014} \\
\hline & Turnover & $\mathbf{P} / \mathbf{B V}$ & Turnover & $\mathbf{P} / \mathbf{B V}$ & Turnover & $\mathbf{P} / \mathbf{B V}$ & Turnover & $\mathbf{P} / \mathbf{B V}$ & Turnover & P/BV & Turnover & $\mathbf{P} / \mathbf{B V}$ \\
\hline Decile 1 & $1,0 \%$ & $1,28 \mathrm{x}$ & $5,4 \%$ & $1,28 \mathrm{x}$ & $0,5 \%$ & $0,90 \mathrm{x}$ & $0,5 \%$ & $1,06 \mathrm{x}$ & $1,7 \%$ & $0,77 \mathrm{x}$ & $0,7 \%$ & $1,22 \mathrm{x}$ \\
\hline Decile 2 & $2,2 \%$ & $0,96 \mathrm{x}$ & $29,1 \%$ & $0,72 \mathrm{x}$ & $1,0 \%$ & $1,02 \mathrm{x}$ & $1,4 \%$ & $0,70 \mathrm{x}$ & $4,2 \%$ & $1,30 \mathrm{x}$ & $3,4 \%$ & $1,02 \mathrm{x}$ \\
\hline Decile 3 & $3,9 \%$ & $0,97 x$ & $28,0 \%$ & $0,82 \mathrm{x}$ & $2,1 \%$ & $0,78 \mathrm{x}$ & $2,4 \%$ & $0,59 \mathrm{x}$ & $7,1 \%$ & $1,01 x$ & $5,7 \%$ & $1,24 \mathrm{x}$ \\
\hline Decile 4 & $5,6 \%$ & $1,18 \mathrm{x}$ & $30,8 \%$ & $1,05 x$ & $3,6 \%$ & $0,83 \mathrm{x}$ & $3,3 \%$ & $0,97 \mathrm{x}$ & $10,3 \%$ & $1,06 x$ & $7,2 \%$ & $1,35 \mathrm{x}$ \\
\hline Decile 5 & $8,6 \%$ & $1,03 x$ & $40,7 \%$ & $1,36 \mathrm{x}$ & $5,8 \%$ & $0,72 \mathrm{x}$ & $4,8 \%$ & $0,78 \mathrm{x}$ & $14,0 \%$ & $1,53 \mathrm{x}$ & $9,1 \%$ & $2,00 \mathrm{x}$ \\
\hline Decile 6 & $12,1 \%$ & $0,88 \mathrm{x}$ & $58,9 \%$ & $0,82 \mathrm{x}$ & $8,3 \%$ & $0,76 \mathrm{x}$ & $6,7 \%$ & $1,04 \mathrm{x}$ & $18,6 \%$ & $2,83 \mathrm{x}$ & $13,5 \%$ & $1,51 \mathrm{x}$ \\
\hline Decile 7 & $16,1 \%$ & $1,51 \mathrm{x}$ & $64,7 \%$ & $1,32 \mathrm{x}$ & $10,9 \%$ & $1,01 \mathrm{x}$ & $11,1 \%$ & $0,99 \mathrm{x}$ & $24,2 \%$ & $1,09 \mathrm{x}$ & $19,0 \%$ & $1,30 \mathrm{x}$ \\
\hline Decile 8 & $22,0 \%$ & $1,24 \mathrm{x}$ & $59,5 \%$ & $1,39 \mathrm{x}$ & $21,3 \%$ & $1,26 \mathrm{x}$ & $16,3 \%$ & $1,39 \mathrm{x}$ & $29,3 \%$ & $0,98 \mathrm{x}$ & $28,2 \%$ & $1,95 \mathrm{x}$ \\
\hline Decile 9 & $30,1 \%$ & $1,68 \mathrm{x}$ & $73,6 \%$ & $1,01 \mathrm{x}$ & $30,1 \%$ & $1,16 \mathrm{x}$ & $28,1 \%$ & $1,65 \mathrm{x}$ & $40,4 \%$ & $1,25 \mathrm{x}$ & $37,6 \%$ & $0,96 \mathrm{x}$ \\
\hline Decile 10 & $61,5 \%$ & $1,17 \mathrm{x}$ & $80,8 \%$ & $1,64 \mathrm{x}$ & $63,6 \%$ & $0,71 \mathrm{x}$ & $61,3 \%$ & $0,52 x$ & $76,4 \%$ & $1,37 \mathrm{x}$ & $68,5 \%$ & $0,94 \mathrm{x}$ \\
\hline Median Whole Sample & $10,1 \%$ & $1,19 x$ & $8,9 \%$ & $1,12 \mathrm{x}$ & $7,1 \%$ & $0,88 x$ & $5,5 \%$ & $0,83 x$ & $15,7 \%$ & $0,16 x$ & $10,2 \%$ & $0,11 x$ \\
\hline Implied Discount - Deci & & $-9,4 \%$ & & $21,8 \%$ & & $-26,7 \%$ & & $-102,2 \%$ & & $43,7 \%$ & & $-30,6 \%$ \\
\hline Implied Discount - Med & & $-24,0 \%$ & & $6,0 \%$ & & $-26,1 \%$ & & $-36,2 \%$ & & $49,5 \%$ & & $38,9 \%$ \\
\hline Correlation & & $31,6 \%$ & & $36,8 \%$ & & $-0,2 \%$ & & $-4,4 \%$ & & $9,6 \%$ & & $-29,4 \%$ \\
\hline
\end{tabular}

\begin{tabular}{|c|c|c|c|c|c|c|c|c|c|c|}
\hline & \multicolumn{2}{|l|}{2015} & \multirow{2}{*}{$\begin{array}{c}2016 \\
\text { Turnover }\end{array}$} & \multicolumn{3}{|c|}{2017} & \multicolumn{2}{|c|}{2018} & \multicolumn{2}{|c|}{2019} \\
\hline & Turnover & P/BV & & P/BV & Turnover & P/BV & Turnover & P/BV & Turnover & P/BV \\
\hline Decile 2 & $3,2 \%$ & $0,99 \mathrm{x}$ & $2,9 \%$ & $0,91 \mathrm{x}$ & $4,1 \%$ & $2,31 x$ & $2,4 \%$ & $1,40 \mathrm{x}$ & $14,4 \%$ & $2,50 \mathrm{x}$ \\
\hline Decile 4 & $7,6 \%$ & $1,21 x$ & $5,5 \%$ & $1,58 \mathrm{x}$ & $10,1 \%$ & $1,42 \mathrm{x}$ & $6,2 \%$ & $1,68 \mathrm{x}$ & $35,6 \%$ & $1,24 \mathrm{x}$ \\
\hline Decile 5 & $10,1 \%$ & $3,12 x$ & $8,8 \%$ & $1,35 \mathrm{x}$ & $12,7 \%$ & $2,99 \mathrm{x}$ & $8,6 \%$ & $1,98 \mathrm{x}$ & $46,5 \%$ & $1,42 \mathrm{x}$ \\
\hline Decile 6 & $13,6 \%$ & $1,88 \mathrm{x}$ & $14,5 \%$ & $1,71 \mathrm{x}$ & $15,3 \%$ & $2,14 \mathrm{x}$ & $11,8 \%$ & $1,83 \mathrm{x}$ & $61,6 \%$ & $2,37 x$ \\
\hline Decile 8 & $27,6 \%$ & $1,51 \mathrm{x}$ & $24,4 \%$ & $2,29 \mathrm{x}$ & $24,5 \%$ & $1,68 \mathrm{x}$ & $18,9 \%$ & $1,62 x$ & $100,4 \%$ & $1,56 \mathrm{x}$ \\
\hline Decile 9 & $34,5 \%$ & $2,08 \mathrm{x}$ & $34,8 \%$ & $1,51 \mathrm{x}$ & $35,6 \%$ & $1,41 \mathrm{x}$ & $24,0 \%$ & $1,22 \mathrm{x}$ & $139,7 \%$ & $1,50 \mathrm{x}$ \\
\hline Decile 10 & $58,4 \%$ & $1,36 \mathrm{x}$ & $87,5 \%$ & $0,87 \mathrm{x}$ & $68,2 \%$ & $0,74 \mathrm{x}$ & $47,8 \%$ & $0,87 x$ & $280,6 \%$ & $0,79 \mathrm{x}$ \\
\hline Median Whole Sample & $11,1 \%$ & $0,12 x$ & $10,9 \%$ & $0,12 x$ & $13,8 \%$ & $0,14 x$ & $10,1 \%$ & $0,10 x$ & $53,9 \%$ & $0,54 x$ \\
\hline \multicolumn{2}{|c|}{ Implied Discount - Decile 10 vs Decile 1} & $5,5 \%$ & & $4,5 \%$ & & $-35,2 \%$ & & $-14,4 \%$ & & $-104,5 \%$ \\
\hline
\end{tabular}
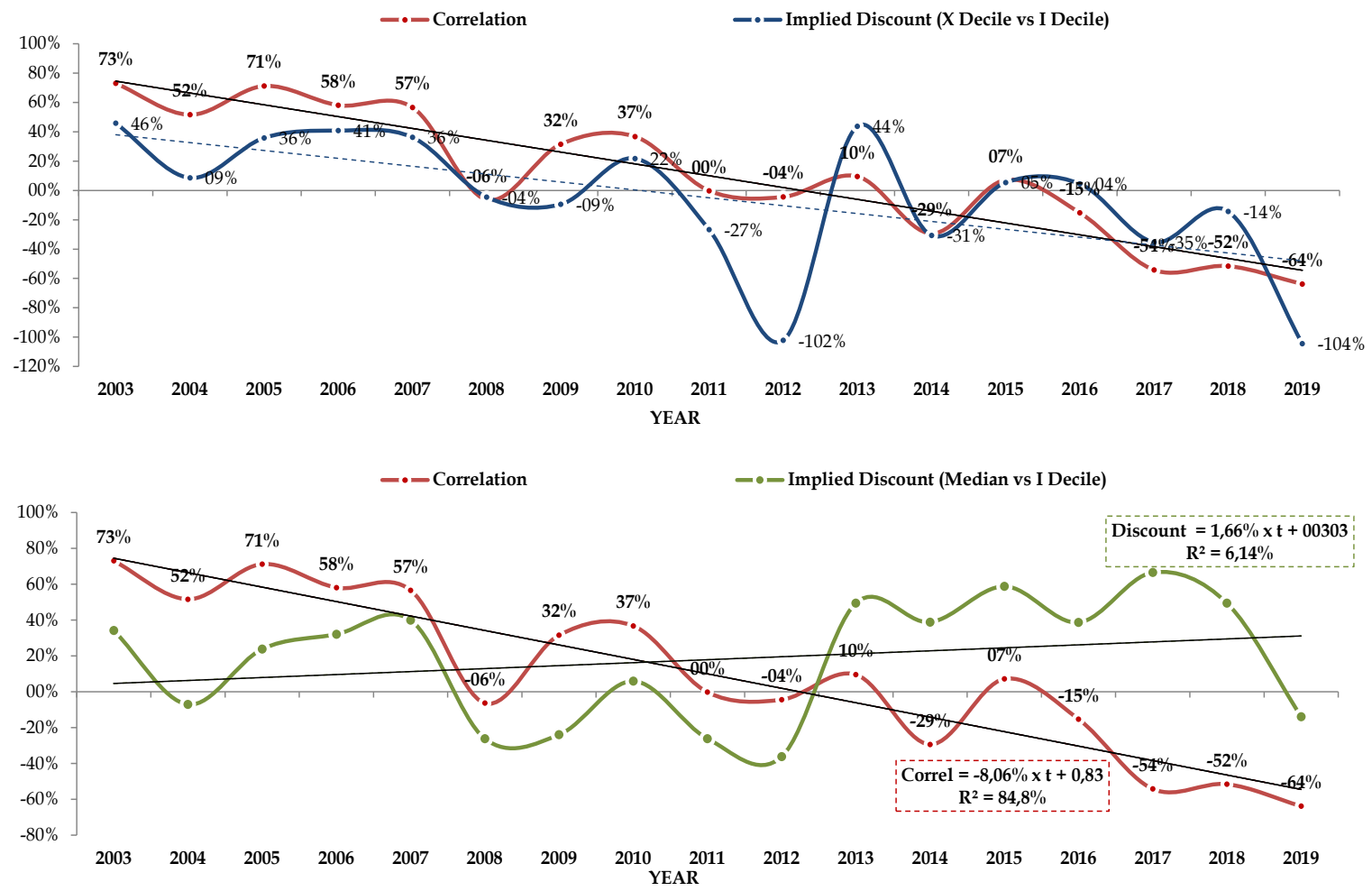

Figure 1. Trend for: i) the liquidity discount and ii) the correlation between liquidity of shares and the P/BV multiple in the seventy-year period from 2003-2019 


\section{Relationship between Price to Book Value and liquidity}

The analysis comparing the first and tenth deciles indicated in the previous point (and showing that, in 2012, there was no relationship between stock market multiples and share liquidity) was completed with a regression analysis on the Price to Book Value multiple in relation to the turnover indicator. This additional analysis had two specific purposes: a) to verify the statistical significance, by examining the p-level coefficient, the slope of the regression (i.e. the turnover beta) and consequently the impact of liquidity on the formation of stock market prices regardless of which decile the company is in and b) to corroborate the discount measurements identified in the previous analysis. Where the regression coefficients are significant, it is possible to calculate the lack of liquidity implicit in a financial market as the percentage difference between: $i$ ) the P/BV multiple of an illiquid company (turnover equal to zero) and $i i$ ) the P/BV multiple of a liquid company with turnover equal to the median of the most liquid companies (top decile in the related frequency distribution). The formulas:

$$
\mathrm{P} / \mathrm{BV}=\alpha+\beta \times \text { Turnover }
$$

Once the regression coefficients $\alpha$ and $\beta$, and the median turnover are known, the liquidity discount can be calculated as follows:

Discount for lack of liquidity $=1-\left[\alpha /\left(\alpha+\beta\right.\right.$ Turnover $\left.\left._{\text {Median }}\right)\right]$

To simplify the calculations, the analysis took advantage of the observations as per the 10 deciles indicated in table 1. Nonetheless, the same regression analysis was conducted on the entire sample of 305 listed Italian companies, obtaining the same results for the statistical significance of the turnc ... _xplanatory variable.

Figure 2 and table 5 provide a summary of the results in relation to:

1. The significance of the turnover variable;

2. The implicit liquidity discount in financial markets.

It shows that:

1. For 2003 to 2007 , the turnover variable is statistically significant and the related coefficient is always positive around one. In other terms, there is a positive relationship between turnover and the $\mathrm{P} / \mathrm{BV}$ multiple, with the companies with greater liquidity having a higher P/BV multiple. Therefore, liquidity during this historical period of time contributed significantly to the level of the stock exchange multiples.

2. Starting from 2008 , the turnover variable lost statistical significance and the related coefficient became unstable (negative in 2008, 2012-2014, 2017-2019 and positive in 2009 - 2011, 2015-2016). This shows that, from 2008, the relationship between P/BV and turnover lost significance and, consequently, share liquidity did not help to explain the level of the P/BV multiple.

3. As a consequence of the observations in points 1 and 2, in 2003 to 2007, given the significance of the $\mathrm{P} / \mathrm{BV}$ to turnover ratio, it is possible to calculate the liquidity discount, which is positive with a median value of $29.3 \%$. By contrast, for 2008 to 2019 , the liquidity discount $i$ ) loses economic significance (because of the drop in significance of the P/BV - turnover ratio) and ii) effectively becomes zero (median equals $-5.4 \%$ ).

In short, both the analysis using the deciles and the regression analysis show the liquidity discount varies over time.

\section{Conclusions}

The analysis conducted made it possible to verify:

a) the existence for the Italian market of a discount for lack of liquidity for shares with less turnover;

b) the variability over time of that discount, thus agreeing with the literature that has found the premiums for liquidity risk vary over time.

The discounts that were found are, nonetheless, smaller than those indicated in the literature. The descending trend over time for the discount would seem to be particularly consistent with the studies on restricted stocks.

Table 5 Trends for: i) the significance of the P/BV ratio compared to Turnover and ii) the liquidity discount for the ten-year period from 2003-2019 


\begin{tabular}{|c|c|c|c|c|c|c|c|c|c|c|}
\hline & 2003 & 2004 & 2005 & 2006 & 2007 & 2008 & 2009 & 2010 & 2011 & $\begin{array}{r}\text { Median } \\
2003-2007\end{array}$ \\
\hline \multicolumn{11}{|l|}{ Coefficient } \\
\hline Intercept (a) & $1,30 x$ & $1,59 x$ & $1,58 x$ & $1,84 x$ & $1,72 x$ & $1,01 x$ & $1,12 x$ & $0,92 x$ & $0,91 x$ & $1,59 x$ \\
\hline Turnover (b) & $1,77 x$ & $0,94 x$ & $1,06 x$ & $1,20 x$ & $0,80 x$ & $-0,12 x$ & $0,43 x$ & $0,46 x$ & $0,00 x$ & $1,06 x$ \\
\hline Significance (p-level) of turnover variable & $1,6 \%$ & $12,6 \%$ & $2,1 \%$ & $7,8 \%$ & $8,8 \%$ & $86,2 \%$ & $37,4 \%$ & $29,6 \%$ & $99,6 \%$ & $0,08 x$ \\
\hline Tenth Decile Turnover (c) & $56,8 \%$ & $65,0 \%$ & $72,3 \%$ & $63,5 \%$ & $77,0 \%$ & $44,4 \%$ & $61,5 \%$ & $80,8 \%$ & $63,6 \%$ & $0,65 x$ \\
\hline Impied P/BV Tenth decile Turnover $\left(\mathrm{d}=\mathrm{a}+\mathrm{b}^{*} \mathrm{c}\right)$ & $2,31 x$ & $2,19 x$ & $2,34 x$ & $2,60 x$ & $2,33 x$ & $0,96 x$ & $1,39 x$ & $1,30 \mathrm{x}$ & $0,91 \mathrm{x}$ & $2,33 x$ \\
\hline \multirow[t]{2}{*}{ Discount for lack of liquidity $(e=d-a)$} & $43,5 \%$ & $27,7 \%$ & $32,7 \%$ & $29,3 \%$ & $26,3 \%$ & $-5,7 \%$ & $19,2 \%$ & $28,7 \%$ & $-0,1 \%$ & $29,3 \%$ \\
\hline & 2012 & 2013 & 2014 & 2015 & 2016 & 2017 & 2018 & 2019 & $\begin{array}{r}\text { Median } \\
2008- \\
2019 \\
\end{array}$ & \\
\hline \multicolumn{11}{|l|}{ Coefficient } \\
\hline Intercept (a) & $0,98 x$ & $1,81 x$ & $1,84 x$ & $1,96 x$ & $1,71 x$ & $2,70 x$ & $2,14 x$ & $2,32 x$ & $1,81 x$ & \\
\hline Turnover (b) & $-0,08 x$ & $-0,44 x$ & $-0,24 x$ & $0,62 x$ & $1,26 x$ & $-1,46 x$ & $-1,22 x$ & $-0,23 x$ & $-0,08 x$ & \\
\hline Significance (p-level) of turnover variable & $90,4 \%$ & $62,8 \%$ & $78,3 \%$ & $60,6 \%$ & $11,5 \%$ & $29,6 \%$ & $37,8 \%$ & $34,3 \%$ & $37,8 \%$ & \\
\hline Tenth Decile Turnover (c) & $61,3 \%$ & $68,5 \%$ & $68,5 \%$ & $58,4 \%$ & $87,5 \%$ & $68,2 \%$ & $47,8 \%$ & $280,6 \%$ & $68,2 \%$ & \\
\hline Impied P/BV Tenth decile Turnover $\left(\mathrm{d}=\mathrm{a}+\mathrm{b}^{*} \mathrm{c}\right)$ & $0,93 x$ & $1,51 x$ & $1,68 \mathrm{x}$ & $2,33 x$ & $2,82 x$ & $1,70 \mathrm{x}$ & $1,56 \mathrm{x}$ & $1,66 \mathrm{x}$ & $1,56 \mathrm{x}$ & \\
\hline Discount for lack of liquidity $(\mathrm{e}=\mathrm{d}-\mathrm{a})$ & $-5,4 \%$ & $-19,9 \%$ & $-9,8 \%$ & $15,6 \%$ & $39,1 \%$ & $-58,2 \%$ & $-37,5 \%$ & $-39,5 \%$ & $-5,4 \%$ & \\
\hline
\end{tabular}

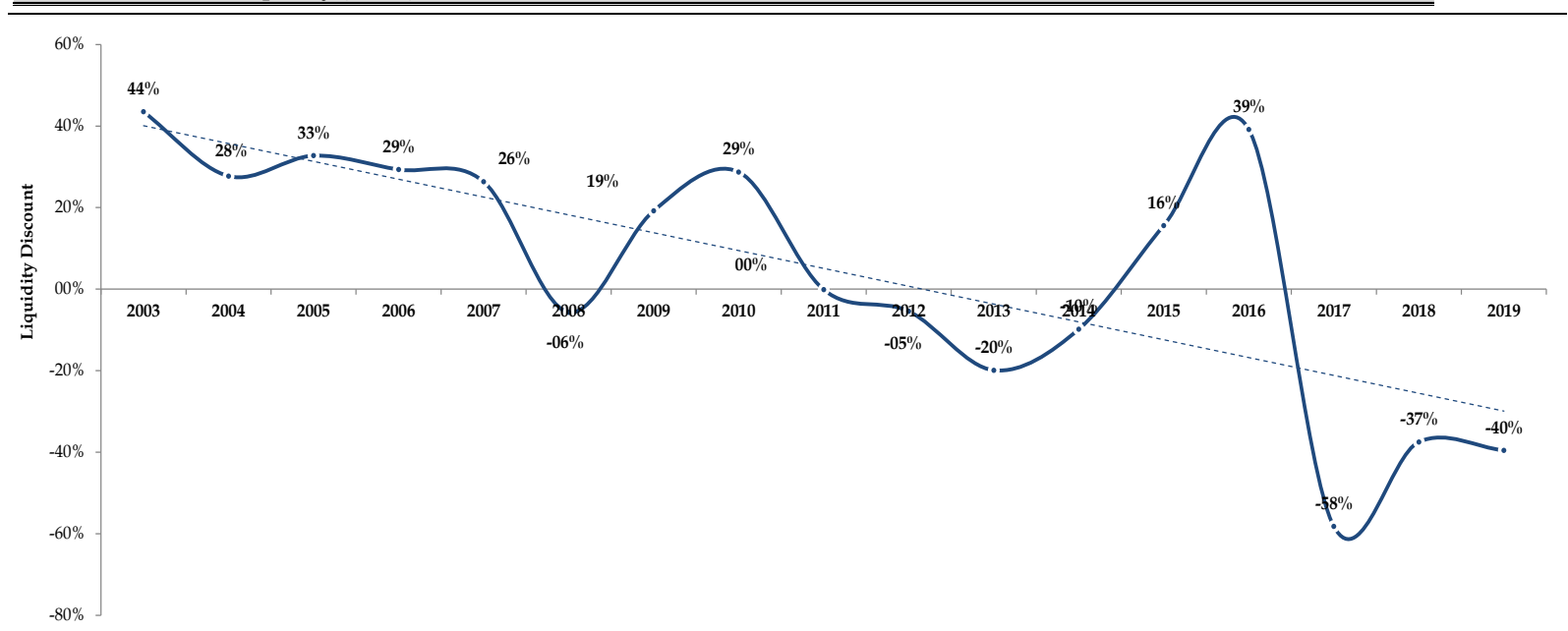

Figure 2. Trends for: i) the significance of the P/BV ratio compared to Turnover and ii) the liquidity discount for the ten-year period from 2003-2019 
Table 6. Summary of i) the analysis using deciles and ii) the regression analysis

\begin{tabular}{|c|c|c|c|c|c|c|c|c|c|}
\hline \multirow{2}{*}{$\frac{2003}{\text { Decile } 1}$} & \multirow{2}{*}{$\frac{\text { Turnover }}{2,0 \%}$} & $P$ to $B V$ & \multicolumn{3}{|c|}{ Regression analysis - $\mathbf{P} / \mathbf{B V}$ is Turnover } & \multirow[b]{3}{*}{ Coeff. } & \multirow[b]{3}{*}{ Std.Err. } & \multirow[b]{3}{*}{$\mathbf{t}(\mathbf{1 0 4})$} & \multirow[b]{3}{*}{ p-level } \\
\hline & & $1,29 \mathrm{x}$ & \multirow[b]{2}{*}{2003} & \multirow[b]{2}{*}{ Value } & & & & & \\
\hline Decile 2 & $3,1 \%$ & $1,41 x$ & & & & & & & \\
\hline Decile 3 & $4,7 \%$ & $1,52 x$ & Multiple R & $73,1 \%$ & Intercept & 1,30 & 0,14 & 9,59 & $0,0 \%$ \\
\hline Decile 4 & $7,2 \%$ & $1,41 x$ & Multiple $\mathrm{R}^{2}$ & $53,4 \%$ & Turnover & 1,77 & 0,58 & 3,03 & $1,6 \%$ \\
\hline Decile 5 & $9,3 \%$ & $1,96 x$ & Adjusted $\mathrm{R}^{2}$ & $47,6 \%$ & & & & & \\
\hline Decile 6 & $11,8 \%$ & $1,43 x$ & $\mathrm{~F}(1,104)$ & 9,17 & Liquidity d & count & & & $43,5 \%$ \\
\hline Decile 7 & $16,3 \%$ & $1,01 x$ & $\mathrm{p}$ & 0,02 & & & & & \\
\hline Decile 8 & $23,9 \%$ & $1,49 \mathrm{x}$ & Std.Err. of Estimate & 0,30 & & & & & \\
\hline Decile 9 & $32,3 \%$ & $2,08 \mathrm{x}$ & & & & & & & \\
\hline Decile 10 & $56,8 \%$ & $2,38 \mathrm{x}$ & & & & & & & \\
\hline Implicit dis & Decile 1 & $45,8 \%$ & & & & & & & \\
\hline Correlation & & $73,1 \%$ & & & & & & & \\
\hline
\end{tabular}

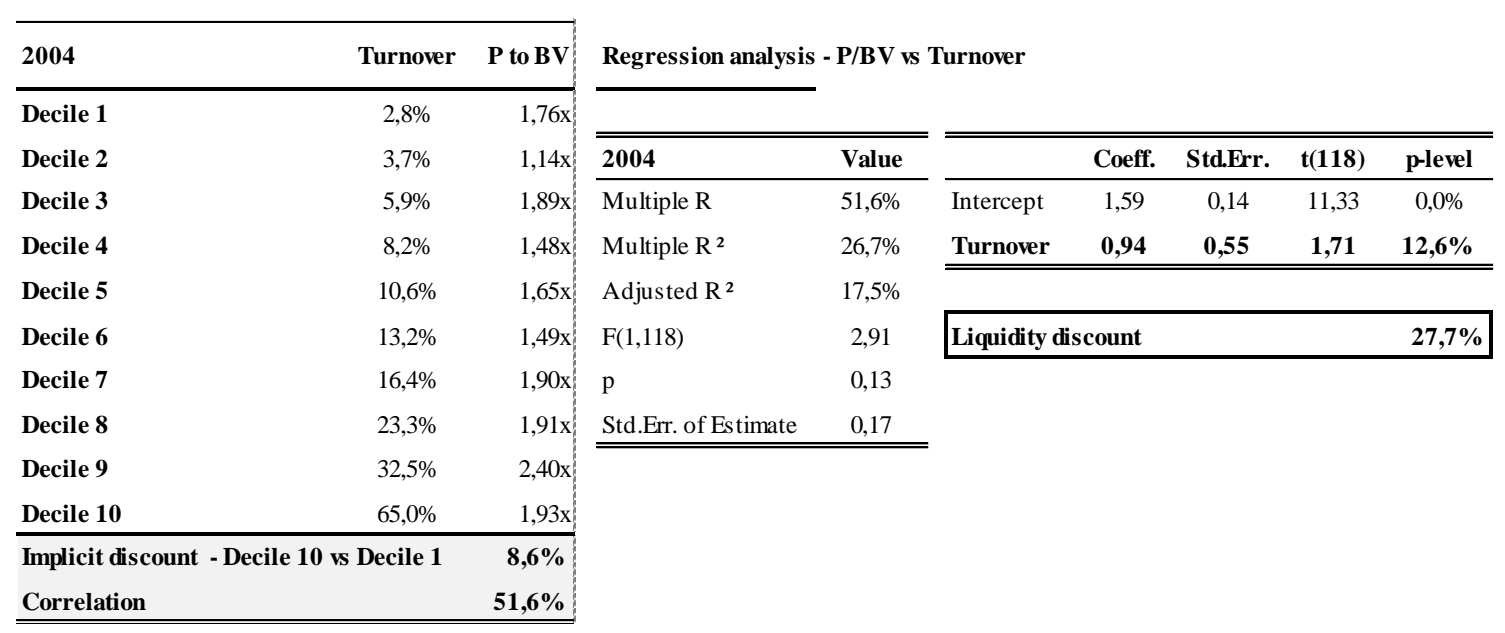

\begin{tabular}{|c|c|c|c|c|c|c|c|c|c|}
\hline \multirow{2}{*}{$\frac{2005}{\text { Decile } 1}$} & \multirow{2}{*}{$\frac{\text { Turnover }}{2,9 \%}$} & \multirow{2}{*}{$\frac{\mathbf{P} \text { to } \mathbf{B V}}{1,38 \mathrm{x}}$} & \multicolumn{3}{|c|}{ Regression analysis $-\mathrm{P} / \mathrm{BV}$ vs Turnover } & \multirow[b]{3}{*}{ Coeff. } & \multirow[b]{3}{*}{ Std.Err. } & \multirow[b]{3}{*}{$\mathbf{t}(\mathbf{1 3 3})$} & \multirow[b]{3}{*}{ p-level } \\
\hline & & & \multirow[b]{2}{*}{2005} & \multirow[b]{2}{*}{ Value } & & & & & \\
\hline Decile 2 & $4,5 \%$ & $1,49 \mathrm{x}$ & & & & & & & \\
\hline Decile 3 & $7,1 \%$ & $1,67 \mathrm{x}$ & Multiple R & $71,2 \%$ & Intercept & 1,58 & 0,11 & 14,34 & $0,0 \%$ \\
\hline Decile 4 & $9,4 \%$ & $1,82 \mathrm{x}$ & Multiple $\mathrm{R}^{2}$ & $50,7 \%$ & Turnover & 1,06 & $\mathbf{0 , 3 7}$ & 2,87 & $2,1 \%$ \\
\hline Decile 5 & $11,5 \%$ & $1,82 \mathrm{x}$ & Adjusted $\mathrm{R}^{2}$ & $44,6 \%$ & & & & & \\
\hline Decile 6 & $17,2 \%$ & $1,86 x$ & $\mathrm{~F}(1,133)$ & 8,24 & Liquidity c & count & & & $32,7 \%$ \\
\hline Decile 7 & $22,7 \%$ & $1,43 x$ & $\mathrm{p}$ & 0,02 & & & & & \\
\hline Decile 8 & $27,3 \%$ & $2,14 x$ & Std.Err. of Estimate & 0,16 & & & & & \\
\hline Decile 9 & $42,0 \%$ & $2,29 \mathrm{x}$ & & & & & & & \\
\hline Decile 10 & $72,3 \%$ & $2,16 \mathrm{x}$ & & & & & & & \\
\hline Implicit dis & Decile 1 & $35,9 \%$ & & & & & & & \\
\hline Correlatio & & $71,2 \%$ & & & & & & & \\
\hline
\end{tabular}




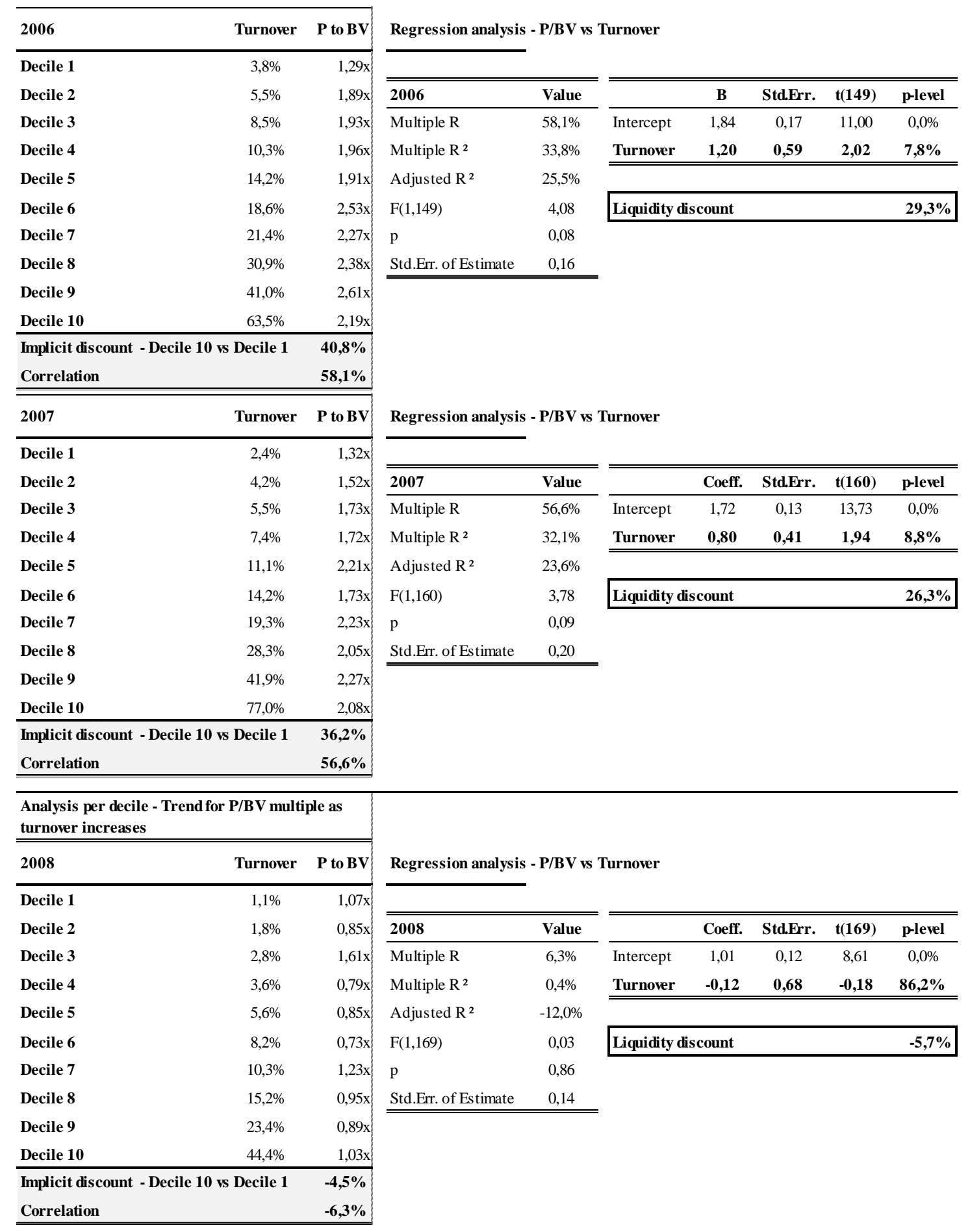




\begin{tabular}{|c|c|c|c|c|c|c|c|c|c|}
\hline \multirow{2}{*}{$\begin{array}{l}2009 \\
\text { Decile } 1\end{array}$} & Turnover & $\mathbf{P}$ to $\mathbf{B V}$ & \multicolumn{3}{|c|}{ Regression analysis - P/BV vs Turnover } & \multirow[b]{3}{*}{ Coeff. } & \multirow[b]{3}{*}{ Std.Err. } & \multirow[b]{3}{*}{$\mathbf{t}(\mathbf{1 7 4})$} & \multirow[b]{3}{*}{ p-level } \\
\hline & $1,0 \%$ & $1,28 \mathrm{x}$ & \multirow[b]{2}{*}{2009} & \multirow[b]{2}{*}{ Value } & & & & & \\
\hline Decile 2 & $2,2 \%$ & $0,96 x$ & & & & & & & \\
\hline Decile 3 & $3,9 \%$ & $0,97 x$ & Multiple R & $31,6 \%$ & Intercept & 1,12 & 0,11 & 10,20 & $0,0 \%$ \\
\hline Decile 4 & $5,6 \%$ & $1,18 \mathrm{x}$ & Multiple $\mathrm{R}^{2}$ & $10,0 \%$ & Turnover & $\mathbf{0 , 4 3}$ & $\mathbf{0 , 4 6}$ & 0,94 & $37,4 \%$ \\
\hline Decile 5 & $8,6 \%$ & $1,03 x$ & Adjusted $\mathrm{R}^{2}$ & $-1,3 \%$ & & & & & \\
\hline Decile 6 & $12,1 \%$ & $0,88 \mathrm{x}$ & $\mathrm{F}(1,174)$ & 0,89 & Liquidity d & count & & & $19,2 \%$ \\
\hline Decile 7 & $16,1 \%$ & $1,51 x$ & $\mathrm{p}$ & 0,37 & & & & & \\
\hline Decile 8 & $22,0 \%$ & $1,24 x$ & Std.Err. of Estimate & 0,18 & & & & & \\
\hline Decile 9 & $30,1 \%$ & $1,68 x$ & & & & & & & \\
\hline Decile 10 & $61,5 \%$ & $1,17 x$ & & & & & & & \\
\hline Implicit dis & S Decile 1 & $-9,4 \%$ & & & & & & & \\
\hline Correlation & & $31,6 \%$ & & & & & & & \\
\hline 2010 & Turnover & $P$ to $B V$ & \multicolumn{3}{|c|}{ Regression analysis - P/BV vs Turnover } & & & & \\
\hline Decile 1 & $5,4 \%$ & $1,28 \mathrm{x}$ & & & & & & & \\
\hline Decile 2 & $29,1 \%$ & $0,72 x$ & 2010 & Value & & Coeff. & Std.Err. & $\mathbf{t}(\mathbf{1 7 8})$ & p-level \\
\hline Decile 3 & $28,0 \%$ & $0,82 x$ & Multiple R & $36,8 \%$ & Intercept & 0,92 & 0,22 & 4,28 & $0,3 \%$ \\
\hline Decile 4 & $30,8 \%$ & $1,05 x$ & Multiple $\mathrm{R}^{2}$ & $13,5 \%$ & Turnover & 0,46 & $\mathbf{0 , 4 1}$ & 1,12 & $29,6 \%$ \\
\hline Decile 5 & $40,7 \%$ & $1,36 x$ & Adjusted $\mathrm{R}^{2}$ & $2,7 \%$ & & & & & \\
\hline Decile 6 & $58,9 \%$ & $0,82 x$ & $\mathrm{~F}(1,178)$ & 1,25 & Liquidity di & count & & & $28,7 \%$ \\
\hline Decile 7 & $64,7 \%$ & $1,32 x$ & $\mathrm{p}$ & 0,30 & & & & & \\
\hline Decile 8 & $59,5 \%$ & $1,39 x$ & Std.Err. of Estimate & 0,24 & & & & & \\
\hline Decile 9 & $73,6 \%$ & $1,01 x$ & & & & & & & \\
\hline Decile 10 & $80,8 \%$ & $1,64 \mathrm{x}$ & & & & & & & \\
\hline \multicolumn{2}{|c|}{ Implicit discount - Decile 10 ss Decile 1} & $21,8 \%$ & & & & & & & \\
\hline Correlation & & $36,8 \%$ & & & & & & & \\
\hline 2011 & Turnover & $\mathbf{P}$ to $\mathrm{BV}$ & \multicolumn{4}{|c|}{ Regression analysis - P/BV us Turnover } & & & \\
\hline Decile 1 & $0,5 \%$ & $0,90 x$ & & & & & & & \\
\hline Decile 2 & $1,0 \%$ & $1,02 x$ & 2011 & Value & & Coeff. & Std.Err. & $\mathbf{t}(\mathbf{1 7 6})$ & p-level \\
\hline Decile 3 & $2,1 \%$ & $0,78 \mathrm{x}$ & Multiple R & $0,2 \%$ & Intercept & 0,91 & 0,08 & 11,26 & $0,0 \%$ \\
\hline Decile 4 & $3,6 \%$ & $0,83 x$ & Multiple $\mathrm{R}^{2}$ & $0,0 \%$ & Turnover & $\mathbf{0 , 0 0}$ & $\mathbf{0 , 3 4}$ & $-0,01$ & $99,6 \%$ \\
\hline Decile 5 & $5,8 \%$ & $0,72 x$ & Adjusted $\mathrm{R}^{2}$ & $-12,5 \%$ & & & & & \\
\hline Decile 6 & $8,3 \%$ & $0,76 x$ & $\mathrm{~F}(1,176)$ & 0,00 & Liquidity di & count & & & $-0,1 \%$ \\
\hline Decile 7 & $10,9 \%$ & $1,01 x$ & $\mathrm{p}$ & 1,00 & & & & & \\
\hline Decile 8 & $21,3 \%$ & $1,26 x$ & Std.Err. of Es timate & 0,21 & & & & & \\
\hline Decile 9 & $30,1 \%$ & $1,16 x$ & & & & & & & \\
\hline Decile 10 & $63,6 \%$ & $0,71 \mathrm{x}$ & & & & & & & \\
\hline Implicit dis & s Decile 1 & $-26,7 \%$ & & & & & & & \\
\hline Correlation & & $-0,2 \%$ & & & & & & & \\
\hline
\end{tabular}




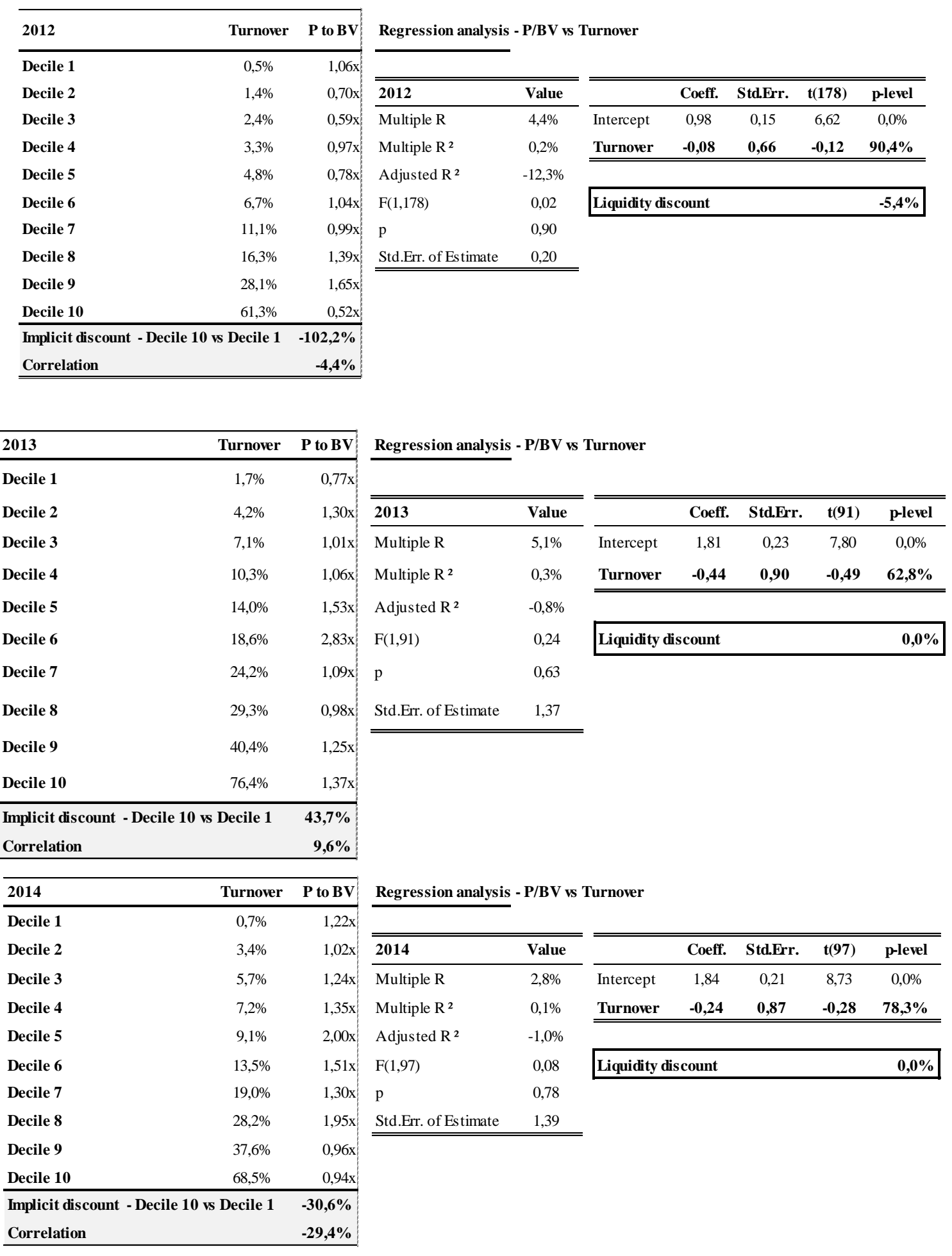




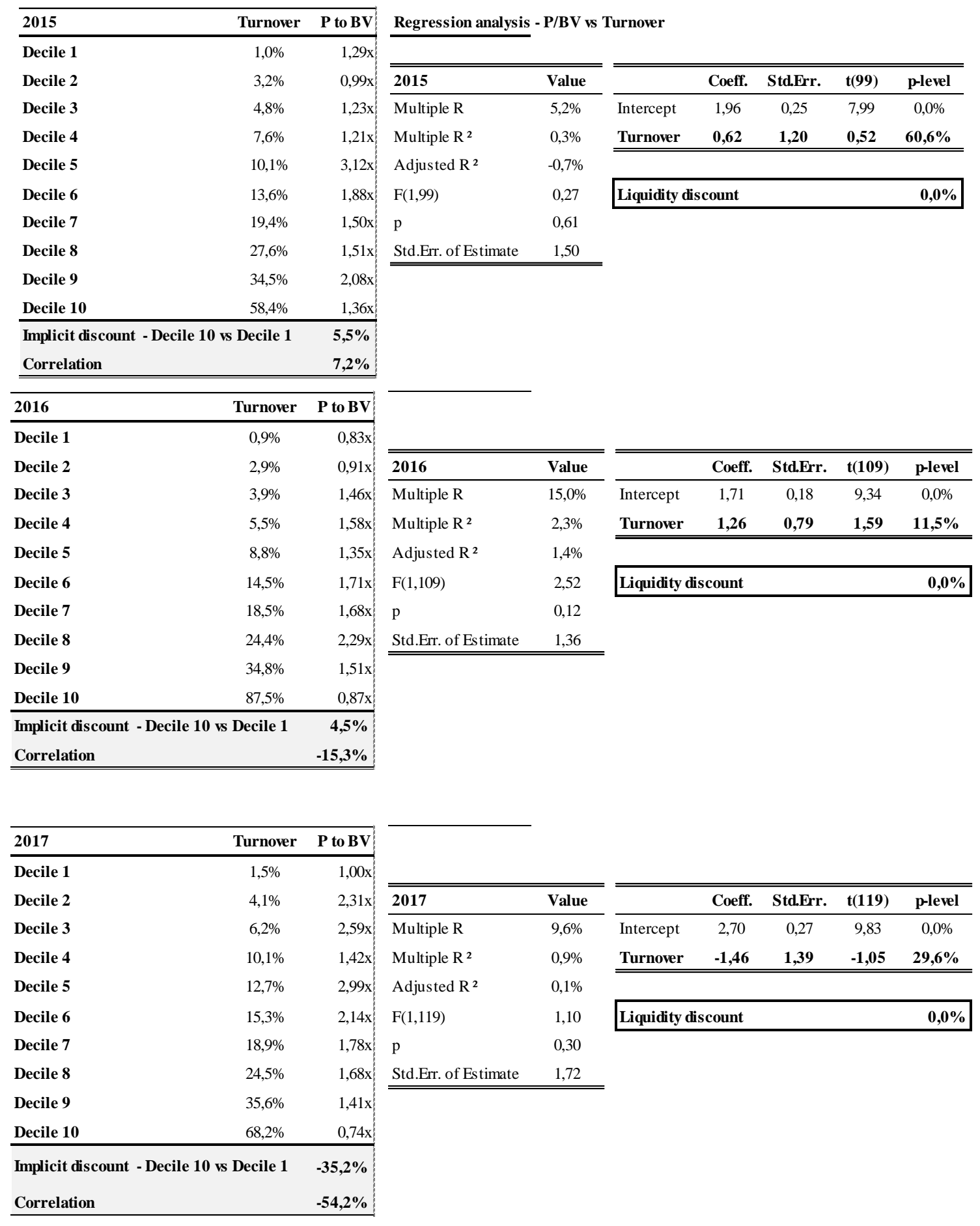




\begin{tabular}{|c|c|c|c|c|c|c|c|c|c|}
\hline 2018 & Turnover & $P$ to $B V$ & \multirow[b]{3}{*}{2018} & \multirow[b]{3}{*}{ Value } & \multirow{3}{*}{\multicolumn{2}{|c|}{ Coeff. }} & \multirow[b]{3}{*}{ Std.Err. } & \multirow[b]{3}{*}{$\mathbf{t}(\mathbf{1 2 3})$} & \multirow[b]{3}{*}{ p-level } \\
\hline Decile 1 & $1,1 \%$ & $1,00 x$ & & & & & & & \\
\hline Decile 2 & $2,4 \%$ & $1,40 x$ & & & & & & & \\
\hline Decile 3 & $4,4 \%$ & $2,07 x$ & Multiple R & $7,9 \%$ & Intercept & 2,14 & 0,22 & 9,56 & $0,0 \%$ \\
\hline Decile 4 & $6,2 \%$ & $1,68 x$ & Multiple $\mathrm{R}^{2}$ & $0,6 \%$ & Turnover & $-1,22$ & 1,38 & $-0,88$ & $37,8 \%$ \\
\hline Decile 5 & $8,6 \%$ & $1,98 x$ & Adjusted $\mathrm{R}^{2}$ & $-0,2 \%$ & & & & & \\
\hline Decile 6 & $11,8 \%$ & $1,83 x$ & $\mathrm{~F}(1,123)$ & 0,78 & \multicolumn{2}{|c|}{ Liquidity discount } & & & $\mathbf{0 , 0 \%}$ \\
\hline Decile 7 & $15,0 \%$ & $1,57 x$ & $\mathrm{p}$ & 0,38 & & & & & \\
\hline Decile 8 & $18,9 \%$ & $1,62 x$ & Std.Err. of Estimate & 1,55 & & & & & \\
\hline Decile 9 & $24,0 \%$ & $1,22 x$ & & & & & & & \\
\hline Decile 10 & $47,8 \%$ & $0,87 x$ & & & & & & & \\
\hline \multicolumn{2}{|c|}{ Implicit discount - Decile 10 vs Decile 1} & $-14,4 \%$ & & & & & & & \\
\hline \multicolumn{2}{|l|}{ Correlation } & $-51,6 \%$ & & & & & & & \\
\hline 2019 & Turnover & $\mathbf{P}$ to $\mathbf{B V}$ & & & & & & & \\
\hline Decile 1 & $4,6 \%$ & $1,62 \mathrm{x}$ & & & & & & & \\
\hline Decile 2 & $14,4 \%$ & $2,50 x$ & 2019 & Value & \multicolumn{2}{|r|}{ Coeff. } & Std.Err. & $\mathbf{t}(\mathbf{1 3 0})$ & p-level \\
\hline Decile 3 & $23,3 \%$ & $1,97 x$ & Multiple R & $8,3 \%$ & Intercept & 2,32 & 0,22 & 10,76 & $0,0 \%$ \\
\hline Decile 4 & $35,6 \%$ & $1,24 \mathrm{x}$ & Multiple $\mathrm{R}^{2}$ & $0,7 \%$ & Turnover & $-0,23$ & 0,25 & $-0,95$ & $34,3 \%$ \\
\hline Decile 5 & $46,5 \%$ & $1,42 \mathrm{x}$ & Adjusted $\mathrm{R}^{2}$ & $-0,1 \%$ & & & & & \\
\hline Decile 6 & $61,6 \%$ & $2,37 x$ & $\mathrm{~F}(1,130)$ & 0,91 & Liquidity & count & & & $0,0 \%$ \\
\hline Decile 7 & $81,9 \%$ & $1,83 \mathrm{x}$ & $\mathrm{p}$ & 0,34 & & & & & \\
\hline Decile 8 & $100,4 \%$ & $1,56 x$ & Std.Err. of Estimate & 1,54 & & & & & \\
\hline Decile 9 & $139,7 \%$ & $1,50 \mathrm{x}$ & & & & & & & \\
\hline Decile 10 & $280,6 \%$ & $0,79 \mathrm{x}$ & & & & & & & \\
\hline Implicit disco & Decile 1 & $-104,5 \%$ & & & & & & & \\
\hline Correlation & & $-63,8 \%$ & & & & & & & \\
\hline
\end{tabular}

\section{References}

Acharya, V. V., \& Pedersen, L. H. (2002). Asset pricing with liquidity risk. working paper, Stern School of Business. https://doi.org/10.2139/ssrn.366300

Amihud, Y., \& Mendelson, H. (1986). Asset pricing and the bid-ask spread. Journal of Financial Economics, 17. https://doi.org/10.1016/0304-405X(86)90065-6

Amihud, Y., \& Mendelson, H. (1989). The effects of beta, bid-ask spread, residual risk and size on stock returns. Journal of Finance, 44. https://doi.org/10.1111/j.1540-6261.1989.tb05067.x

Bagna, E. (2012). La Valutazione delle Banche. EGEA, ISBN 9788823843332.

Bagna, E. (2018). Is There Any Value in the Banks Brand? International Journal of Business and Management, 13(12), 2018. https://doi.org/10.5539/ijbm.v13n12p261

Bagna, E., \& Cotta Ramusino, E. (2017). Market Multiples and the Valuation Cyclical Companies. International Business Research, 10(12). https://doi.org/10.5539/ibr.v10n12p246

Bagna, E., \& Di Martino, G. (2013). La value relevance della fair value hierarchy nel settore bancario europeo. Finanza Marketing e Produzione, 4.

Bagna, E., Bini, M., Bird, R., Momentè, F., \& Reggiani, F. (2010). Accounting for employee stock options: What can we learn from the market's perceptions? Journal of International Financial Management \& Accounting 21(2), 161-186. https://doi.org/10.1111/j.1467-646X.2010.01039.x

Bagna, E., Di Martino, G., \& Rossi, D. (2015). No more discount under enhanced fair value hierarchy. Applied Economics, 47(51). https://doi.org/10.1080/00036846.2015.1054068

Bagna, E., Dicuonzo, G., Perrone, A., \& Dell'Atti, V. (2017). The value relevance of brand valuation. Applied Economics, 49(58). https://doi.org/10.1080/00036846.2017.1352078 
Bajaj, M., Denis, D., Ferris, S., \& Sarin, A. (2001). Firm value and marketability discount. Journal of Corporate Law, 27. https://doi.org/10.2139/ssrn.262198

Chaffee, D. III (1993). Option pricing as a proxy for discount for lack of marketability in private company valuations. Business Valuation Review. https://doi.org/10.5791/0882-2875-12.4.182

Chordia, T., Roll, R., \& Subrahmanyam, A. (2000). Commonality in liquidity. Journal of Financial Economics, 56. https://doi.org/10.1016/S0304-405X(99)00057-4

Damodaran, A. (2005). Marketability and value: measuring the illiquidity discount. working paper. https://doi.org/10.2139/ssrn.841484

Datar, V., Naik, N., \& Radcliffe, R. (1998). Liquidity and stock returns: an alternative test. Journal of Financial Markets, 1. https://doi.org/10.1016/S1386-4181(97)00004-9

Emory, J. (1997). The value of marketability as illustrated in initial public offerings of common stocks (eight in series), November 1995-1997. Business Valuation Review, 16, 1997. https://doi.org/10.5791/0882-2875-16.3.123

Emory, J. (2002). Discounts for lack of marketability Emory pre-IPO discount studies 1980-2000. working paper. https://doi.org/10.5791/0882-2875-21.4.190

Finnerty, J. (2002). The impact of transfer restriction on stock prices. working paper. https://doi.org/10.2139/ssrn.342840

Gelman, M. (1972). An economist-financial analyst approach to valuing stock of a closely held company. Tax'n, 36.

Hertzel, M., \& Smith, R. L. (1993). Market discounts and shareholder gains from placing equity privately. Journal of Finance, 48. https://doi.org/10.1111/j.1540-6261.1993.tb04723.x

Hitchner, J. (2003). Financial valuation. John Wiley and Sons.

Johnson, B. A. (1999). Quantitative support for discounts for lack of marketability. Business Valuation Review, 16. https://doi.org/10.5791/0882-2875-18.4.152

Koeplin, J., Sain, A., \& Shapiro, A. C. (2000). The private company discount. Journal of applied corporate finance, 12, 2000. https://doi.org/10.1111/j.1745-6622.2000.tb00022.x

Maher, J. M. (1976). Discounts for lack of marketability for closely held business interests. Taxes, 54.

Pastor, L., \& Stambaugh, R. F. (2003). Liquidity risk and expected stock returns. Journal of Political Economy 111. https://doi.org/10.1086/374184

Pratt, S. (2001). Business valuation discounts and premium. John Wiley and Sons.

SEC. (1971). Institutional investor study report of the securities and exchange commission 2444-56.

Silber, W. (1991). Discounts on restricted stocks: the impact of illiquidity on stock prices. Financial Analyst Journal, 47. https://doi.org/10.2469/faj.v47.n4.60

Trout, R. (1977). Estimation of the discount associated with the transfer of restricted securities. Taxes, 55.

\section{Copyrights}

Copyright for this article is retained by the author(s), with first publication rights granted to the journal.

This is an open-access article distributed under the terms and conditions of the Creative Commons Attribution license (http://creativecommons.org/licenses/by/4.0/). 